(1)
Volume 6, Nomor 1, Tahun 2020
Tersedia Online: http://ojs.uniska.ac.id/index.php/BKA
e-ISSN 2477-6300

\title{
LAYANAN KONSELING INDIVIDUAL DENGAN PENDEKATAN GESTALT UNTUK MENINGKATKAN KEPERCAYAAN DIRI SISWA INTROVERT PADA KELAS VII DI SMP NEGERI 2 MARTAPURA
}

\author{
Pri Agung Warjono, Sultani, Laelatul Anisah \\ Universitas Islam Kalimantan Muhammad Arsyad Al Banjari \\ priagungwarjono@gmail.com
}

\begin{abstract}
ABSTRAK
Pada observasi awal di SMP Negeri 2 Martapura ditemukan siswa yang mempunyai sikap kepercayaan diri rendah, seperti siswa takut maju kedepan untuk menjawab soal karena teman dikelasnya suka mengejek tulisan siswa membuat siswa tersebut takut mengeluarkan pendapat dan bertanya. Tujuan penelitian ini untuk mengetahui peningkatan rasa percaya diri siswa introvert melalui layanan konseling individual dengan pendekatan gestalt pada siswa kelas VII di SMP Negeri 2 Martapura. Penelitian ini menggunakan metode eskperimen dengan singel subject design.subjek penelitian sebanyak 3 siswa yang memiliki rasa kepercayaan diri rendah. Teknik pengumpulan data dengan skala percaya diri. Hasil penelitian menunjukkan bahwa percaya diri pada siswa introvert di kelas VII di SMP Negeri 2 Martapura dalam hasil analisis data dengan Wilcoxon dengan nilai sig 0,109 maka dengan demikian maka analisis tersebut ditolak karena pada dasarnya pengambilan Wilcoxon adalah > 0,05 jika hasilnya lebih besar pada hasil yang sudah ditentukan maka (Ho) ditolak ditolak maka dapat dikatakan jika sampel 3 siswa dapat mempengaruhi hasil signifikan terhadap kepercayaan diri siswa dalam memberikan layanan konseling individual dengan pendekatan gestalt.Saran yang diberikan : kepada guru bimbingan konseling hal menarik dalam siswa agar siswa tertarik menceritakan permasalah mengalami kesulitan dalam kehidupannya, agar siswa berani memiliki sikap, perilaku, dan kepribadian yang positif. Kepada peneliti selanjutnya agar menggunakan waktu dengan sebaik-baiknya.
\end{abstract}

Kata Kunci: Konseling Individual, Pendekatan Gestalt, Percaya Diri

\begin{abstract}
In the initial observation at SMP Negeri 2 Martapura, students who had low self-confidence attitudes were found, as students were afraid to come forward to answer questions because their classmates like to mock students' writing making them afraid to express their opinions and ask questions. The purpose of this study was to determine the increase in self-confidence of introverted students through individual counseling services with a gestalt approach in class VII students at SMP Negeri 2 Martapura. This study used the experimental method with single subject design. The research subjects were 3 students who had low selfesteem. Techniques for collecting data with a scale of confidence.The results showed that confidence in introverted students in class VII in SMP Negeri 2 Martapura in the results of data analysis with Wilcoxon with a sig value of 0.109 so that the analysis was rejected because basically taking Wilcoxon is $>0.05$ if the results are greater on the results which has been determined then $(\mathrm{Ho})$ is rejected rejected so it can be said if the sample of 3 students can influence the significant results on students' confidence in providing individual counseling services with a gestalt approach
\end{abstract}

Keywords: Individual Counseling, Gestalt Approach, Confidence 
Pri Agung Warjono, Sultani, Laelatul Anisah

Jurnal Bimbingan dan Konseling Ar-Rahman

Volume 6, Nomor 1, 2020

e-ISSN 2477-6300

\section{PENDAHULUAN}

Kepercayaan diri dalam bahasa gaul harian, pede yang kita maksudkan adalah percaya diri. Semua orang sebenarnya punya masalah dengan istilah yang satu ini. Ada orang yang merasa telah kehilangan rasa percaya diri dihampir keseluruhan wilayah hidupnya. Mungkin terkait dengan soal krisis diri, depresi, hilang kendali, merasa tak berdaya menatap sisi cerah masa depan, dan lainlain. ada juga orang yang merasa belum pede/percaya diri dengan apa yang dilakukannya atau dengan apa yang ditekuninya. Ada juga orang yang merasa kurang percaya diri ketika menghadapi situasi atau keadaan tertentu. Menurut Goleman (2013:62) bahwa kepercayaan diri adalah kesadaran yang kuat tentang harga dan kemampuan diri sendiri. Anak-anak yang memiliki rasa percaya diri tinggi merupakan pribadi yang bisa dan mau belajar, serta berperilaku positif dalam berhubungan dengan orang lain bahkan orang dewasa sekalipun.

Semua orang pada dasarnya percaya diri akan tetapi yang selalu menjadi kendala disini bagaimana cara mengeluarkan kepercayaan diri yang ada dalam diri kita, contoh kasusnya seperti yang ada di SMP Negeri 2 Martapura yang mengalami kepercayaan diri yang rendah. Selfconfidance (Rasa percaya diri) rasa percaya atau kepercayaan diri adalah bagian yang tidak terpisahkan dari pengarahan diri karena orang harus bisa mempercayai dirinya sendiri sebelum bisa mengarahkan kehidupannya. Orang yang mencari layanan konseling, karena meragukan kemampuan, persepsi, motivasi, dan penilaiannya. Kurang kepercayaan diri, mungkin mereka diajari oleh orang tuannya dan orang lain dengan cara yang salah atau mereka diperlukan dengan overprotective (terlalu dikekang) sehingga mereka hanya memiliki kesempatan yang sedikit untuk menguji diri mereka sendiri dan memperkuat kepercayaan dirinya. Permasalahan, orang yang memiliki rasa kurang percaya diri akan memiliki sifat sebagai berikut : Biasanya siswa tidak memiliki keyakinan pada diri sendiri atau meragukan salah satu area. Contoh kemampuan mereka untuk memasuki hubungan intim. Dalam beberapa kasus, biasanya mereka mengalami frustasi karena mereka sering kali mengetahui apa yang mereka inginkan tetapi memiliki kekurangan kepercayaan diri untuk mengejar atau mempergunakan kemampuan itu.

Siswa mengalami kesulitan dalam membuat keputusan. Karena mereka meragukan dirinya sendiri, mereka mungkin menolak atau menunda waktu untuk membuat keputusan. Dalam kasus seperti itu, kebutuhan mereka yang penting mungkin tidak akan terpenuhi. Frustasi dan kecemasan meningkat baik dalam dirinya mampu orang lain yang terlibat dalam pembuatan keputusan Peserta didik yang berkeinginan untuk sukses itu dalam pendidikan mampu mengembangkan potensi akademiknya maupun non akademiknya di sekolah. Dengan rasa percaya diri siswa akan bisa menunjukkan prestasi di sekolahnya tanpa adanya rasa minder dengan keahlian yang dimiliki pada dirinya karena keahlian yang dimiliki seseorang merupakan sangu. Buat kita yang sangat penting bagi dikehidupan seseorang ketika seseorang percaya, yakin terhadap kemampuan yang ia alami maka diri akan merasa mampu untuk melakukan suatu hal. Kepercayaan yang tinggi yang dimiliki seseorang akan membuat dirinya termotivasi untuk berusaha mencapai tujuannya dan tingkat kesuksesan dalam suatu bidang itu akan mengalami kesulitan yang dicapai jika ia tidak mempunyai tingkat kepercayaan diri yang cukup kepercayaan diri merupakan suatu hal yang perlu kita perhatikan dalam mencapai kesuksesan seseorang. Dibandingkan dengan teman yang lain yang mampu berpikiran positif terhadap sesuatu yang akan dihadapi.

Berdasarkan gambaran penelitian yang terjadi dilapangan tepatnya di SMP Negeri 2 Martapura. Peneliti menemukan siswa yang minder untuk berteman dengan teman yang lain karena sesuai dengan data peliti yang didapatkan, selalu menyendiri dan tidak mau bergaul dengan teman yang lain lantaran dia memiliki masa puber yang begitu cepat dari teman yang lainnya. Kemudian ditambah dengan wawancara dengan siswa yang tidak mempunyai rasa percaya diri, peserta didik menyatakan bahwa selain diri nya malu terhadap teman yang lain, disamping itu juga peserta didik ketika disuruh maju kedepan ragu dalam menjawab pertanyaan yang diberikan oleh gurunya saat proses pembelajaran. Karena komunikasinya kepada teman-temannya di kelas begitu jarang dan saat berbicara selalu merasa ide yang disampaikannya selalu salah. Ketika disuruh untuk bertanya kebanyakan berdiam diri saja. Setelah penelusuran selanjutnya yang dilakukan peneliti aktifitas peserta didik jika di rumah peserta didik selalu menghabiskan waktunya dengan cara bermain game sampai lupa waktu, marah ketika orang tua menyuruh peserta didik untuk membersihkan ruangan rumah.

Kepercayaan diri merupakan modal dasar bagi anak untuk memenuhi kebutuhan hidupnya, yaitu membantu anak agar dapat diterima dilingkungannya. Kepercayaan diri tidak datang dengan sendirinya namun dipengaruhi oleh berbagai faktor. Faktor-faktor tersebut perlu mendapat dukungan dari orang tua, lingkungan, maupun guru di sekolah. Orang tua merupakan 
Pri Agung Warjono, Sultani, Laelatul Anisah Jurnal Bimbingan dan Konseling Ar-Rahman Volume 6, Nomor 1, 2020 e-ISSN 2477-6300

faktor terpenting dalam membangun kepercayaan diri anak. Pendidikan keluarga merupakan pendidikan pertama dan utama yang sangat menentukan baik buruknya kepribadian anak.

Pada orang dengan tipe kepribadian introvert akan lebih berorientasi pada stimulus internal yaitu memperhatikan pikiran. Suasana hati dan reaksi-reaksi yang terjadi dalam diri mereka. Hal ini membuat individu yang tergolong introvert cenderung lebih pemalu, memiliki kontrol diri yang kuat, tampak pendiam, lebih tertutup dengan masalah yang individu alami dan memiliki keterpakuan terhadap hal-hal terjadi dalam diri mereka.

Rahayu (2013:68) mengemukakan bahwa di sekolah, guru dapat memberi dukungan kepada anak melalui tujuan, minat, dan mencari segala potensi diri untuk membangun kepercayaan dirinya. The Can-Do dan Leading Lads merupakan penelitian tentang kepercayaan diri (usia 5-8 tahun). Diketahui bahwa sementara ini ada lebih sedikit anak perempuan yang menunjukkan kepercayaan diri dibandingkan anak laki-laki (perempuan 21\% laki-laki 25\%), ada lebih banyak anak perempuan dibandingkan anak laki-laki yang termasuk kelompok tengah atau kelompok yang sangat percaya diri, da nada lebih sedikit anak perempuan dibandingkan anak laki-laki yang memiliki kepercayaan diri yang rendah (perempuan $8 \%$ lakilaki $12 \%)$.

Peneliti yang dilakukan oleh Asri, Suarmi, dan Arum (2014) menemukan bahwa konseling behavioral teknik Positive Reinforcement efektif untuk meningkatkan rasa percaya diri di dalam belajar siswa kelas VIII SMP N 2 Singaraja. Selain itu, penelitian ini juga mengungkapkan bahwa salah satu cara yang agar dapat meningkatkan percaya diri yaitu dengan melaksanakan konseling individu. Aileen milne (Yusuf, 2016:19) mengemukan bahwa melalui konseling individu memperoleh bantuan untuk memecahkan masalahnya (resolve problems) atau menjalani kehidupan secara lebih bermakna. Salah satu layanan yang dapat dilakukan guru bimbingan dan konseling agar membantu siswa memahami tentang kepercayaan diri yaitu konseling individual. Konseling individual adalah suatu layanan bimbingan dan konseling yang konseli mendapatkan layanan secara langsung tatap muka secara perorangan dengan guru pembimbing dalam membahas pengentasan masalah pribadi yang dialami konseli. Kelebihan konseling individual adalah dengan melaksanakan konseling dalam cara pemberikan bantuannya dilakukan secara bertatap muka dan mengentaskan permasalahan pribadi yang konseli alami sekarang, konselor dapat menyakinkan kepada konseli bahwa setiap orang dapat berubah, dapat mencapai sesuatu, arah evaluasi manusia yang bersifat positif.

Tujuan umum konseling individu adalah membantu klien menstrukturkan kembali masalahnya dan menyadari gaya hidupserta mengurangi penilaian negatif terhadap dirinya sendiri serta perasaan-perasaan inferioritasnya. Melalui Pendekatan Gestalt dengan teknik kursi kosong dapat membantu peserta didik untuk mengenali potensi diri yang dimiliki peserta didik dan seberapa besar peserta didik untuk berubah dan memotivasi peserta didik menjadi seseorang yang lebih baik lagi. Dari beberapa banyaknya teknik di dalam konseling peneliti menggunakan salah satunya adalah teknik kursi kosong ini membantu siswa agar bisa berhubungan dengan perasaan atau sisi dari dirinya sendiri yang diingkarinya; membuat siswa mengalami secara penuh perasaan-perasaan yang bertentangan, dari pada hanya membicarakannya, selanjutnya dengan membantu siswa untuk menyadari bahwa perasaan adalah bagian dari diri yang sangat nyata, teknik ini mencegah siswa memisahkan perasaan. Teknik ini juga bisa membantu siswa untuk mengenali gambaran yang tidak menyenangkan.

Berdasarkan uraian di atas penulis tertarik untuk mengangkat tema yang berjudul dengan masalah yang diteliti bahwa dalam meningkatkan percaya diri pada peserta didik tidak semudah membalikkan kedua belah telapak tangan. Ada beberapa faktor dapat menumbuhkan kepercayaan diri peserta didik, misalnya seperti pengalaman yang menyenangkan, memberikan dukungan yang positif. Melalui pendekatan Gestalt dengan teknik kursi peserta didik akan menyadari potensi yang dia miliki dan termotivasi menjadi lebih baik.

\section{METODE}

Penelitian ini menggunakan Preeksperimental design, yaitu singel subject design dan posttest, sebelum siswa diberikan perlakuan kemudian sesudah diberi perlakuan,populasi siswa dalam penelitian ini adalah siswa kelas VII SMP Negeri 2 Martapura. Tipe desain ini adalah A-B design. Logika baseline menunjukkan suatu pengulangan sekurang-kurangnya dua kondisi yaitu kndisi baseline (A) dan kondisi intervensi (B). Sementara itu untuk menentukan hasil penelitian ini dengan cara menganalisa grafik menyajikannya dari hasil penerepan eksperimen di antaranya grafik kepercayaan diri pada fase baseline dan intervensi oleh karena itu, dalam melakukan penelitian ini dengan desain kasus tunggal akan selalu ada pengukuran target dalam diri pada fase baseline dan pengulangannya pada sekurang-kurangnya satu fase intervensi. Pada tahapan baseline A ini dilaksanakan sebanyak 6 sesi. Pada tahapan ini 
Pri Agung Warjono, Sultani, Laelatul Anisah Jurnal Bimbingan dan Konseling Ar-Rahman Volume 6, Nomor 1, 2020 e-ISSN 2477-6300

subjek diberikan serangkaian soal untuk mengukur sikap kepercayaan dirinya dengan beberapa sesi. Pada tiap sesi subjek penelitian diberikan soal sebanyak 75 butir soal dan dikerjakan secara perindividual. Tujuannya agar melihat sikap awal subjek sebelum dilakukannya treament,sebelum tahapan ini dimulai untuk persiapan peneliti diantaranya adalah meyiapkan alat-alat yang pada nantinya akan digunakan pada baseline A (tahap awal) dan baseline B (treatment) Gambaran desain penelitian yang digunakan dapat dilihat pada gambar 1.

$$
\text { A - B }
$$

Gambar 1. Desain Penelitan Logika Baseline

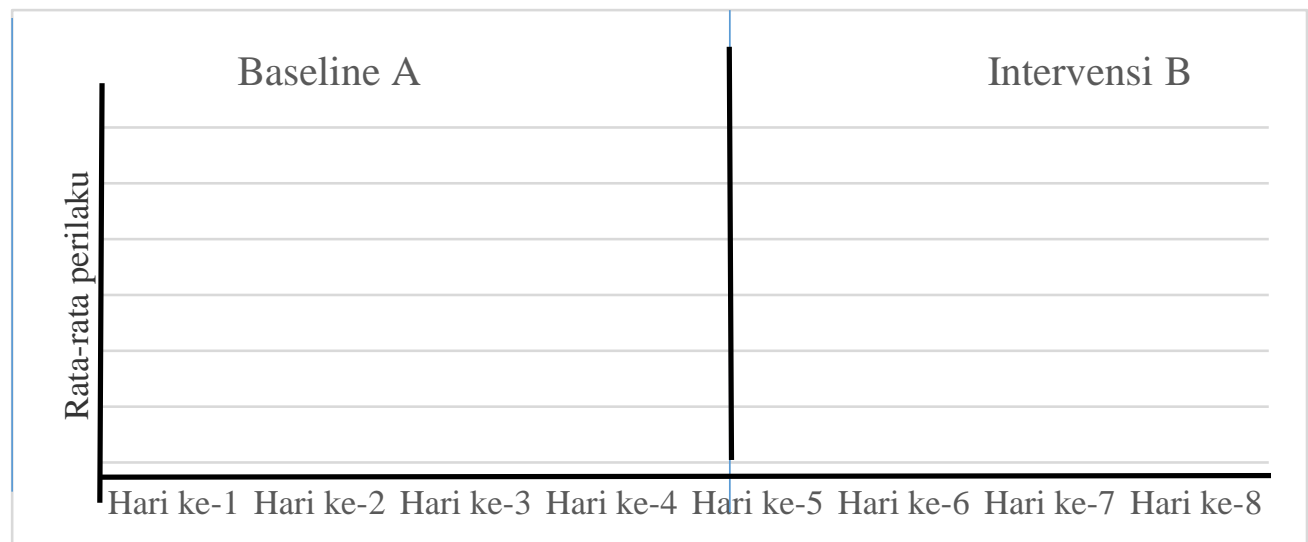

Gambar 2. Fase Baseline dan Intervensi

Berdasarkan hasil skor angket skala kepercayaann diri diambil sampel 3 orang siswa yang memiliki skor terendah untuk diberikan perlakuan layanan konseling individual dengan pendekatan Gestalt. Setelah itu akan dibandingkan keadaan sebelum dan sesudah diberi perlakuan dan akan di uji dengan teknik analisis data yaitu uji wilcoxon

\section{HASIL DAN PEMBAHASAN}

Berdasarkan hasil penelitian tingkat disiplin siswa kelas VII SMP Negeri 2 Martapura sebelum diberikan pendekatan Gestalt dalam penggunaan layanan konseling individual dalam penggunaan layanan konseling individual maka diketahui hasilnya sebagaimana terdeskripsikan pada tabel 1 . Kemudian untuk membuktikan hipotesis yang sudah diajukan dalam penelitian ini maka dilakukan uji dengan analisis wilcoxon yang hasilnya dapat dilihat pada tabel 2 .

Tabel 1. Hasil pretest dan posttest

\begin{tabular}{cccccc}
\hline No. & Responden & Sebelum & Kategori & Sesudah & Kategori \\
\hline 1 & M.Z N & 201 & Tinggi & 216 & Tinggi \\
2 & M.A W & 205 & Tinggi & 262 & Sangat Tinggi \\
3 & A I & 208 & Tinggi & 233 & Tinggi \\
\hline & Jumlah & 614 & & 711 & \\
\hline
\end{tabular}

Tabel 2. Hasil Analisis Wilcoxon

\begin{tabular}{cccccc}
\hline Data & $\mathbf{Z}$ & Asymp.Sig & $\mathbf{< 0 , 0 5}$ & $>\mathbf{0 , 0 5}$ & Keterangan \\
\hline sebelum-sesudah & $-1.604^{\mathrm{b}}$ & 0,109 & Diterima & Tidak diterima & Diterima \\
\hline
\end{tabular}

Berdasarkan tabel 1 dan 2 diatas dapat dilihat bahwa data Sebelum dan Sesudah hasil analisis menggunakan wilcoxon pada aplikasi SPSS menunjukan nilai Asymp.Sig sebesar 0,109 dengan demikian hasil analisis tersebut ditolak karena dasar pengambilan keputusan wilcoxon adalah > 0,05 yang berarti (Ho) ditolak maka dapat dikatakan jika sampel 3 siswa dapat mempengaruhi hasil signifikan terhadap kepercayaan diri siswa dalam 
Pri Agung Warjono, Sultani, Laelatul Anisah Jurnal Bimbingan dan Konseling Ar-Rahman Volume 6, Nomor 1, 2020

e-ISSN 2477-6300

memberikan layanan konseling individual dengan pendekatan Gestalt.

Berdasarkan penjelasan hasil penelitian pada sebelum diberikan pendekatan Gestalt dalam penggunaan layanan konseling individual untuk meningkatkan kepercayaan diri siswa introvert, tidak ditemukan siswa yang memiliki kategori skor (Rendah), (Sangat Rendah), dan (Sangat Tinggi). Adapun kategori skor interval pada sebelum dan sesudah terdapat 3 orang siswa yang memiliki kategori skor Tinggi, sesudah dilakukannya pemberian layanan konseling individual dengan pendekatan Gestalt berubah menjadi 1 orang siswa yang memiliki skor Tinggi.

\section{PENUTUP}

Berdasarkan pada hasil penelitian dengan pendekatan Gestalt dalam penggunaan layanan konseling individual untuk meningkatkan kepercayaan diri siswa pada SMP Negeri 2 Martapura sebagai berikut : (1) Kepercayaan diri siswa M.ZN, MAW, INR sebelum mendapatkan intervensi dengan kategori tinggi dalam skor teredah; (2) Kepercayaan diri siswa M.ZN, M.AW, INR sesudah mendapatkan intervensi mengalami kenaikan nilai skor M.AW menjadi kategori sangat tinggi; (3)Terdapat perbedaan signifikan sebelum dan sesudah melakukan layanan konseling individual dengan pendekatan gestalt untuk meningkatkan kepercayaan diri siswa introvert dengan nilai sig. $=0,109>0,05$, maka dapat dinyatakan bahwa jumlah sampel sedikit dalam pemberian layanan konseling individual dengan pendekatan gestalt tidak efektif untuk meningkatkan kepercayaan diri siswa introvert terhadap populasi.

Berdasarkan hasil penelitian diketahui bahwa kepercayaan diri siswa pada kelas VII SMP Negeri 2 Martapura, berkenaan dengan hal tersebut peneliti dapat memberikan saran: (1) kepada guru bimbingan dan konseling hendaknya dapat membantu siswa dalam membentuk dan mengembangkan percaya diri dengan memberikan suatu layanan konseling individual dengan pendekatan Gestalt, selain itu juga tempat pelaksanaan pemberian layanan konseling individual diusahakan diruangan khusus konseling tujuannya supaya tidak tergganggu dengan suasana diluar; (2) kepada siswa yang mempunyai kategori tinggi untuk dimaksimalkan lagi, dan siswa yang mempunyai kategori sangat tinggi kedepannya dipertahankan dengan cara siswa mengikuti konseling individual jika mengalami kesulitan dalam kehidupannya, agar siswa berani memiliki sikap, perilaku, dan kepribadian yang positif; (3) agat dalam penelitian selanjutnya cara mengatur waktu, tempat tidak terbentur jam pelajaran siswa, tujuannya untuk mendapatkan data yang lebih akurat dan dalam pengambilan sampel minimal lebih banyak dari peneliti sebelumnya agar dalam pelaksanaan layanan konseling individual dengan pendekatan Gestalt efektif untuk meningkatkan kepercayaan diri siswa introvert dapat diterima terhadap populasi.

\section{REFERENSI}

Arikunto, S. (2013). Prosedur Penelitian: Suatu Pendekatan Praktik. Jakarta: Rineka Cipta

Asri, N. L., Suarni, N.K., Putri, D.A.W., \& Ps, S. (2014). Efektifitas konseling behavioral dengan teknik positive reinforcement untuk meningkatkan rasa kepercayaan diri dalam belajar pada siswa kelas VIII SMP Negeri 2 Singaraja Tahun Pelajaran 2013/2014. Ejournal Undiksha Jurusan Bimbingan dan Konseling, 2 (1), 1-10.

De Angelis, B. (2003). Percaya Diri: Sumber dan Kemandirian. Jakarta: Gramedia

Erford, B.T. (2017). 40 Teknik yang Harus Diketahui Setiap Konselor. Yogyakarta: Pustaka Pelajar

Hakim, T. (2002). Mengatasi Rasa Tidak Percaya Diri. Jakarta: Puspa Swara

Marjanti, S. (2015). Upaya meningkatkan rasa kepercayaan diri melalui konseling kelompok bagi siswa X IPS 6 SMA 2 Bae kudus tahun pelajaran 2014/2015. Jurnal Konseling Gusjigang, 1(2).

Rahayu, A.Y. (2013). Menumbuhkan Kepercayaan Diri Melalui Kegiatan Bercerita. Jakarta: PT. Indeks

Sugiyono (2016). Metode Penelitian Pendidikan Pendekatan Kuantitatif, Kualitatif, dan $R \& D$. Bandung: Alfabeta

Taylor, R (2003) Confidence in Just Seven Days: Meraih Kepercayaan Diri Hanya Dalam Tujuh Hari. Jogjakarta: Diva Press.

Usta, H.G. (2017). Examination of the relationship between TEOG Score Transition from Basic to Secondary Education), self-confidence, self-efficacy and motivation level. Journal of Education and Practice, 8(6), 36-47.

Yusuf, S. (2013). Konseling Individual Konsep Dasar \& Pendekatan. Bandung: Grasindo. 